\title{
ST. KAROL WOJTYLA AND ST. EDITH STEIN ON HUMAN INDIVIDUALITY: "PAUSING AT THE IRREDUCIBLE" AND WHY THINK ABOUT IT
}

\author{
Jose Adriand Emmanuel L. Layug \\ Immaculate Conception Major Seminary \\ Bulacan, Philippines
}

\begin{abstract}
We seldom read Wojtyla and Stein being studied together on the issue concerning human individuality, especially in the Englishspeaking world. However, as Mette Lebech (2002, 155) accurately states, both philosophers "illustrate one another." This paper wants to fill this lacuna. The focus is on the issue of human individuality, according to Wojtyla and Stein. However, as the title suggests, the stress is not merely on what they said about human individuality but also equally on why we should think about it. Human individuality is often misunderstood because it is often presented as what and not necessarily inviting others to question why. To limit the scope of the paper, the author will not present the entire thinking on human individuality of the two philosophers. However, it would like to take some preliminary steps to introduce the readers to Wojtyla's and Stein's thoughts on human individuality by focusing on their early works and summon the readers to a not-so-often discussed source of human dignity. Thus, this work is more inviting and suggestive than complete and comprehensive.

The paper has three parts. The first is to spell out the basic outlines of human individuality, according to Wojtyla and Stein. The second part consists of why think about human individuality. The second division is an attempt to be an expression of "pausing at the irreducible," a phrase borrowed from Wojtyla. In the third and last part, the author poses some questions, and attempted answers are given, hoping that these may prompt future studies regarding the subject at hand.
\end{abstract}

\section{INTRODUCTION}

St. Karol Wojtyla and St. Edith Stein have many convergences and differences. It is worthwhile first to see them briefly. First, their convergences: both experienced the death of one of their parents at a young age (Wojtyla his mother while Stein her father), both used the phenomenological method, both stress the 
philosophy of the human person, both were influenced by great philosophers and theologians such as Edmund Husserl, Max Scheler, St. Thomas Aquinas, and St. John of the Cross, (the first doctoral thesis of Wojtyla is on St. John of the Cross while the last work to be written by Stein is also on St. John of the Cross), both have matured thoughts on Christian philosophy and the relationship between faith and reason, both were schooled in the Carmelite tradition, both experienced the horrors of the second world war and were victims of totalitarian regimes (i.e. Communism and Nazism. Stein even experienced the two world wars. She served as a volunteer nurse in the First World War and was killed during the second.), both were canonized saints, and to date, both were being considered to be endowed with the title doctors of the church because their writings significantly contributed to the study and deepening of Divine Revelation which impact the present world most especially the young. Second, their difference: Stein is a convert from Judaism while Wojtyla is not. Stein entered the cloistered monastery of Cologne, while God has other plans for Wojtyla. He originally planned to join the discalced Carmelites, but he was ordained a diocesan priest and rose to the ranks of the hierarchy until he became pope in 1978 . Stein met a martyr's death in the hands of the Nazis while Wojtyla lived longer and served the See of Peter for over a quarter of a century. It was Wojtyla who beatified (1987) and canonized (1998) Stein, mentioned her name in Fides et Ratio \# 74 and proclaimed her co-patroness of Europe in 1999 together with St. Catherine of Siena and St. Bridget of Sweden.

On the other hand, we seldom read Wojtyla and Stein being studied together on the issue concerning human individuality, especially in the English-speaking world. However, as Mette Lebech $(2002$, 155) accurately states, both philosophers "are alike and have much in common; they illustrate one another." This paper's humble attempt is to provide some reasons why Lebech's assertion is true and to fill in this lacuna.

The paper focuses on the issue of human individuality, based on the thoughts of the two great philosophers and saints of the $20^{\text {th }}$ century: Wojtyla and Stein. To limit the scope of the paper, the author does not wish to present the entire thinking on human individuality of the two philosophers for space and time constraints. However, it would like to take some preliminary and introductory steps to introduce the audience to Wojtyla's and Stein's thoughts on human individuality by focusing on their seminal/early works and inviting the hearers to a not-so-often discussed source of human dignity. It will be the task of future studies to inquire into their other and later works deeply. It is also not the task of the present paper to compare the thought of the two thinkers, which this author thinks is very worthwhile. He also lets others take this huge work. Thus, this work is modest in its aim. It is more inviting and suggestive than complete and comprehensive.

The paper has three parts. The first part spells out the basic outlines of human individuality, according to Wojtyla and Stein. The second part consists of why think about human individuality according to these two thinkers. It is an attempt to be an expression of "pausing at the irreducible," a phrase borrowed from Wojtyla. In the third and last part, it poses some questions and gives preliminary replies, with the hope that these questions may prompt future studies regarding the subject at hand. 
Some terms must be clarified before we proceed. Sarah Borden Sharkey (2010, 16-25) made key distinctions which this author follows: human individuation, human individuality, identity, and uniqueness. Without going into details and entering into complicated debates and at the same time trying to avoid the trap of oversimplification, human individuation refers to that which is responsible for many beings or singular instances of the same type. On the other hand, the question of identity asks about how the same human individual persists over time. The issue of human individuality does not only refer to what makes this human individual an individual in itself and different at least numerically from the rest of human beings. We want to take the term human individuality in the strict sense of uniqueness, quantitatively and qualitatively, and in the strong sense of the word. The meaning of "uniqueness" strongly expresses as concretely as possible that something in me (i.e., I am) cannot possibly be replicated, duplicated, and imitated.

\section{BRIEF SKETCH OF HUMAN INDIVIDUALITY ACCORDING TO ST. KAROL WOJTYLA AND ST. EDITH STEIN}

\section{St. Karol Wojtyla}

\section{The Distinction between the Cosmological and the Personalist Approach}

Let us begin with the word "subjectivity." In the short essay "Subjectivity and the Irreducible in the Human Being," in Wojtyla's (1993, 209-217) book Person and community, he claims that man can be studied and viewed in two ways: the cosmological and the personal. The cosmological runs the risk of reducing man to being like any other thing in the world, and thereby failing to see what is characteristic of him as a person. However, Wojtyla is quick to add that this is not to say that the validity of the cosmological way should not be acknowledged. He (1993, 211) argues:

The usefulness of the Aristotelian definition [man as rational animal] is unquestionable. It became the dominant view in metaphysical anthropology and spawned a variety of particular sciences, which likewise understood the human being as an animal with the distinguishing feature of reason. The whole scientific tradition concerning the composition of the human nature, the spiritual compositum humanum - a tradition that came down from the scholastics to Descartes - moved within the framework of this definition and, consequently, within the context of the belief that the essentially human is basically reducible to the world.

The point here is that as Wojtyla $((1993,210 ; 1993,211)$ says, "we can no longer go on treating the human being exclusively as an objective being," "as one of the objects in the world to which the human being visibly and physically belongs." The cosmological approach in itself is insufficient. It must be complemented by the personalist view that sees man not only in terms of potentiality, substance, nature, 
and rationality, man as a rational animal, but also in terms of self-presence, selfdetermination, self-possession, interiority, and self-gift. The cosmological view sees a man from without, while the personalist view sees a man from within. From without, we can only see man's behavior and his physical actuations. From within, we can see his existence and subjectivity. If only seen from without, one can miss the "person" in him.

Subjectivity, as understood here, refers primarily to man's interiority in contrast to how man is viewed cosmologically. Wojtyla $(1993,211 ; 1993,210 ; 1993$, $214 ; 1993,215)$ explains that it is "a kind of synonym for the irreducible in the human being" "that which is original and essentially human, that which accounts for the human being's complete uniqueness in the world." "Irreducible also refers to everything in the human being that is invisible and wholly internal and whereby each human being, myself included, is an 'eyewitness' of his or her own self - of his or her own humanity and person." "Irreducible signifies that which is essentially incapable of reduction, that which cannot be reduced but can only be disclosed or revealed." In subjectivity, man's personhood is disclosed and revealed.

However, at the outset, we must say that we do not wish to lapse into Cartesian solipsism, nor to a form of individual self-absorption nor to deny the social dimension of the human being. Wojtyla himself would disagree. We are saying here is that any philosophy of the person must take into account and has much to gain from the personalist way of viewing man as Wojtyla understood it.

The term subjectivity, in other words, is a way of relating to myself as a subject without making myself into an object just like the things of the world. Obviously, we do not accept the claim that I cannot see myself as an object. It is rather a subject-subject relation and not a subject-object relationship.

What do we mean when we say subject-subject relation? For instance, I see myself facing a vast world of objects that extends far beyond me. In facing this world, I am turned outwards to worlds over against me. Every now and then, I find myself among objects, and my only possible contact with it is as an object of my attention. But what about myself? Is the only possible contact about myself by way of an object? The answer is no! Because whenever I am turned outside of myself, I am in touch with myself, I am present to myself. My encounter with myself as a presence is different from my encounter with things as an object. According to Wojtyla, this is what we refer to as subject-subject relation, the irreducible character of man. He $(1993,214)$ says:

We must always leave the greater space in this cognitive effort for the irreducible; we must, as it were, give the irreducible the upper hand when thinking about the human being, both in theory and in practice. For the irreducible also refers to everything in the human being that is invisible and wholly internal and whereby each human being, myself included, is an 'eyewitness' of his or her own self - of his or her own humanity and person.

Whenever I see myself as an object just like the rest, I am exposed to the public. On the other hand, whenever I relate to myself as a presence, I am hidden and 
not exposed. I am withdrawn from public display. Only I can be present to myself. Only I can encounter myself as self-presence. Nobody can do that for me. You have to be me to do this, which is, of course, impossible.

There is, in other words, a kind of solitude here that only I can experience and encounter. The hiddenness that I experience within me cannot be copied, replicated, shared, nor participated in by anybody else. So unique and irreducible is man's subjectivity that his experience as a subject is his and his alone. In other words, he is incommunicable! ${ }^{2}$ There is a need to understand man not only from the point of view of what is common to all created reality and even from what is common to all human beings. Man is revealed as a person only when he is seen from within. Wojtyla $(1979,83)$ strongly points out:

The experience of man's coherence with all his dynamism, with his acting as well as with what happens to him, allows us to understand how nature is integrated in the person. The integration could not consist solely in the individualization of nature by the person. The person is not merely an "individualized humanness"; it actually consists rather in the mode of individual being that pertains (from among all the types of existing beings) to mankind alone. This mode of being stems from the fact that the peculiar type of being proper to mankind is personal.

Whenever I encounter myself in subject-subject relation, I do not remove myself from other objects of consciousness. Things of which I am conscious of do not compete with my self-presence. On the contrary, the stronger is my self-presence; the stronger is my tendency to turn out of myself. ${ }^{3}$ Echoing Josef Pieper (1998, 9091), this is a kind of consciousness that is different from a subject-object relation.

\section{The Importance of the Lived-Experience and Pausing at the Irreducible}

In the essay, Wojtyla strongly asserts the importance of lived-experience in this way of thinking. Note here is his strong bend and formation on the phenomenological method. Just like above, when he distinguished between the cosmological and personalist approach, he again uses a distinction to highlight the importance of lived-experience, this time the metaphysics of Aristotle. He (1993, 212) starts a strong claim that lived-experience is "a category foreign to Aristotle's metaphysics." The closest that Aristotle has in relation to lived-experience is agere and pati. Wojtyla $(1993,212)$ writes: "These categories serve to describe the dynamism of a being, and they also do a good job of differentiating what merely happens in the human from what the human being does." However, these notions are still not enough to do justice to the person and his subjectivity. Wojtyla $(1993,213)$ goes to the heart of the matter: "For then the issue is not just the metaphysical objectification of the human being as an acting subject, as the agent of acts, but the revelation of the person as a subject experiencing its acts and inner happenings, and with them its own subjectivity."

The need then to "pause at the irreducible" acquires a unique importance. For Wojtyla (1993, 215), "pausing should be understood in relation to the irreducible." It means to say pausing is not in reference to time, as if when I stop, pausing occurs. 
Since the irreducible pertains to man's complete uniqueness and which is also invisible and completely internal, pausing must refer to my awareness, understanding, and appreciation of my uniqueness and that of others, which first occurs in the hiddenness and privacy of my subjectivity. A subject to subject relation can only occur in the atmosphere of "pausing"! In the words of Wojtyla (1993, 213; 1993, 216), "pausing at the irreducible...signifies the kind of methodological operation..." wherein "when we pause at the lived-experience of the irreducible, we attempt to permeate cognitively the whole essence of this experience."

There are many kinds of experiences. I can touch my table and find out that it is smooth. As I reflect on these ideas, I experience the connections and flow of concepts in my mind. But for Wojtyla, lived-experience is more than touching the smoothness of the table or experiencing the flow of ideas in one's mind. Livedexperience is understood by Wojtyla not only in the epistemological sense but more so in the category of the anthropological. This shift of emphasis is important to grasp. In the epistemological sense, the human being is just a sensing subject, someone who experiences what happens in his mind. However, in the anthropological view, man is understood as an experiencing subject, and not just any kind of subject common to all human subjects. He is a subject whose experiences are anchored from within him. So, when man experiences, understood from the anthropological point of view, his experiences reveal his person and subjectivity like no other besides him. He is revealed as this unique and incommunicable being not only to others who see him from the outside and, more importantly, to himself as one who acts. It is in this sense that the term lived-experience is important in understanding the "irreducible in man". Lived-experience is something that cannot be reduced nor canceled by anything outside of him. Lived-experience can only be revealed and shown through the method of phenomenology.

By pausing at the irreducible, which pertains to man's lived experience, we realize that our understanding of man's experience lacks clarity and precision precisely because we only see the dimension of such experience that is outside/external of him. The human being's irreducible character becomes clear to us if the understanding of man's experience includes the way man experiences himself as a unique subject. Wojtyla $(1979,3)$ claims:

This experience, which man has of himself, is the richest and apparently the most complex of all experiences accessible to him. Man's experience of anything outside of him is always associated with the experience of himself, and he never experiences anything external without having at the same time the experience of himself.

Two distinctions must be made to show even more the irreducibility of the human subject: the way man experiences other selves and the way man experiences himself as a subject. The way I, for example, experience the joy of my friends in a birthday party is different from the way I experience the joy within me when I see them as joy-filled. It is clear that the latter has more immediacy and directness than the former. It is revealed in this simple example that no matter how joy-filled my friends are during the party, nobody among them can replace my experience of joy 
within me. The reverse is also true. I cannot possibly put myself into any one of my friends' shoes in order to experience in the same exact manner the way they experience their joy no matter how close I am to my friends. Wojtyla (1979, 5-6) points out: "Even when we assume the closest possible relation to another human being the difference will always remain...everyone is the object of his own unique experience and no external relation to any other human being can take the place of the experiential relation that the subject has to himself."

Essential in pausing at the irreducible for Wojtyla is the correlation between person and action. In fact, it is in the action that human subjectivity, as unique and irreducible person, is revealed. One can also see the person through his action. Wojtyla $(1979,11)$ writes: "Action gives us the best insight into the inherent essence of the person and allows us to understand the person most fully. We experience man as a person, and we are convinced of it because he performs actions."

Cartesian and post-Cartesian philosophy approaches the human being primarily through his cognitive functions. Descartes, for instance, answers the question Who am I? in terms of the thinking self. That is why, for him, it is the nature of the mind to be better known than the body. On the other hand, Wojtyla changes this kind of approach for, obviously, this way of understanding reduces man to just a thinking self. Seen from the phenomenological stance, this is not the case. The unity of every human experience is presupposed in its entirety. Moreover, based on the supposition of the different forms of human experiences, one concludes that the human being is more than just a thinking self.

Wojtyla strongly believes that the person is revealed through his actions. This approach differs sharply from that of Descartes. Human experiences and actions must be taken in their entirety and not split them from the one who acts. Actions are not mere acts observed from the outside. Actions spring forth from within, emanate from the person himself, and ultimately reveal this person. Wojtyla is clear that he does not refer to any kind of subject when he claims that actions reveal persons. He is referring primarily to this unique and irreducible subject as the one who is revealed in actions.

Since the human being in this context is understood not in an abstracted sense, it is also important to note that besides being unique and incommunicable, to pause at the irreducible also means to acknowledge what Wojtyla calls the suppositum. Wojtyla (1993, 222) avers: "To say that the human being - I and every other human being - is given in experience as a suppositum is to say that the whole experience of the human being, which reveals the human being to us as someone who exists and acts, both allows and legitimately requires us to conceive of the human being as the subject of that existence and activity...This concept serves to express the subjectivity of the human being in the metaphysical sense." The human subject must have a ground, a basis, and a guarantor of identity in the midst of his experiences and actions. The human subject cannot possibly be detached from its ontological foundations.

The concept of suppositum further illuminates the relation between the person and his action. This leads once again to our understanding of human subjectivity as unique and irreducible. Using the traditional scholastic operari sequitur esse and giving fresh meaning to it, it is worth noting to quote Wojtyla $(1993,223)$ once again:

From human operari, then, we discover not only that the human 
being is its "sub-ject", but also who the human being is as the subject of his or her activity. Operari, taken as the total dynamism of the human being, enables us to arrive at a more precise and proper understanding of the subjectivity of the human being. By subjectivity here, I am no longer referring to just the suppositum as the subject in the metaphysical sense; I am also referring to everything that, based upon the suppositum, makes the human being an individual, personal subject.

Consciousness is another term that Wojtyla uses to reveal the uniqueness and interiority of human subjectivity. It is something which phenomenology bequeathed to him. Husserl developed it to mean consciousness as consciousness of something other than consciousness itself. Consciousness then always has an object and is intentional. However, towards the latter part of Husserl's philosophy, he veered towards transcendental consciousness, which, according to Wojtyla, seems to understand consciousness as dichotomized from the totality of who man is as irreducible. This error is called subjectivism. Once it happens, consciousness as a category, according to Wojtyla, can no longer account for human subjectivity in the way we understand the term in this paper. Subjectivity is therefore different from subjectivism. He $(1979,58)$ writes: "When consciousness is absolutized, it ance ceases to account for the subjectivity of man, that is to say, his being a subject, or for his actions; and it becomes a substitute for the subject."

Having avoided the mistake of subjectivism (and idealism), Wojtyla uses consciousness to deepen our understanding of the uniqueness of human subjectivity. He $(1979,33)$ takes the meaning of consciousness in the following way: "Disclosing consciousness in the totality of human dynamisms and showing it as the constitutive property of action, we strive to understand it, but always in its relation to the action, to the dynamism and efficacy of the person. This manner of seeing and interpreting consciousness...protects us from conceiving it as an independent, self-contained subject." To bring out the human being's subjectivity, let us remember that the latter has a relationship with others and with himself, as we saw above. Consciousness is that dynamic aspect that lets the human being to have a relationship with himself as a subject without reducing the subject to consciousness (which Wojtyla wants to avoid). The human being as a subject is quite different from the human being's experience of himself as a subject. It is in the latter that consciousness has a key role. More precisely, the role of consciousness is not in the level of the formation of meaning. Rather, as Wojtyla (1979, 32-33) writes:

...the very operation of cognition does not belong to consciousness...As consciousness, we understand then "reflecting consciousness" - that is consciousness in its mirroring function...it means that we recognize this reflecting or mirroring as possible in so far as we attribute to consciousness the specific quality of penetrating and illuminating whatever becomes in any way man's cognitive possession....If we are to keep to this description, the penetrative illumination is rather like keeping objects and their cognitive meanings "in the light" or "in the actual field of consciousness. 
In what way then is man's subjectivity revealed through consciousness understood in the Wojtylan sense? He $(1993,227)$ clearly points out:

Consciousness, insofar as it undoubtedly reflects whatever is objectified cognitively by the human being, at the same time and above all endows this objectified content with the subjective dimension proper to the human being as a subject. Consciousness interiorizes all that the human being cognizes, including everything that the individual cognizes from within in acts of self-knowledge, and makes it all a content of the subject's lived-experience.

In the human being's relation to himself as a subject, consciousness reveals that the experience of oneself as a self is irreplaceable by anybody else. Consciousness sheds further light on the human being's subjectivity and his interiority as unique and incommunicable.

\section{St. Edith Stein}

St. Edith Stein comes from a different angle. Her first strictly phenomenological work is her doctoral dissertation under the supervision of Edmund Husserl entitled On the Problem of Empathy. This was defended in 1916 with the distinction of summa cum laude. This first work was followed by two more treatises (Sentient Causality and Individual and Community) published in Husserl's Yearbook and which were put into one volume when translated into English entitled Philosophy of Psychology and Humanities. These three works were written before her conversion to the Catholic Church in 1922. Although Stein is committed to Husserl's phenomenology, it is also a given fact that she tried to avoid, like Wojtyla, Husserl's transcendental idealism.

When Stein studied psychology at the University of Breslau between 19111913, one of her courses was under William Stern. Before going to Gottingen to study under Husserl, Stein asked Stern what topic she can write under him. Though the paper did not materialize, we can see Stern's influence in Stein's thought in her notion of "core personality." According to Stein (1986, $185 \mathrm{ff})$, this core personality is stable in one's life, a personal structure that each individual possesses. This structure dictates the line of development that each human individual must follow and possesses traits and characteristics yet to be actualized in real life.

For instance, in her dissertation, Stein $(1989,40)$ sees the soul as the bearer or carrier of "persistent attributes" that show themselves in one's conscious life. Stein $(1989,40)$ gives us examples:

The acuteness of our senses apparent in our outer perceptions is such an attribute. Another is the energy apparent in our conduct. The tension or laxity of our volitions manifests the vivacity and strength or the weakness of our will. Its persistence is found in its duration. The intensity of our feelings, the ease with which they appear, the excitability of our sentiments, etc., disclose our disposition. 
Added to that, we find the following passage in her $(1989,110)$ dissertation:

We find not only that the categorical structure of the soul as soul must be retained, but also within its individual form we strike an unchangeable kernel, the personal structure. I can think of Caesar in a village instead of in Rome and can think of him transferred to the $20^{\text {th }}$ century. Certainly, his historically settled individuality would then go through some changes, but he would remain Caesar just as surely. The personal structure marks off a range of possibilities of variation within which the person's real distinctiveness can be developed 'ever according to circumstances. ${ }^{5}$

This means to say there is something stable in the personality structure of Caesar even if he undergoes a myriad of changes. There is something in him that is not affected by changes around him. Time, space, history cannot possibly efface that something in Caesar though it can unfold or not.

For Stein, furthermore, this core cannot be developed ${ }^{6}$ nor deteriorate. It can only manifest itself and unfold based on its essential structures. She $(1989,110)$ writes: "A spiritual subject does not lose a value it feels. Neither can a psychophysical individual be led by a habit to a value for which he lacks the correlative level. The levels of the person do not 'develop' or 'deteriorate,' but they can only be exposed or not in the course of psychic development."7 It can be that in the process of man's development, he can unfold his personality core. But it is also possible that this core cannot unfold depending on his circumstances. Stein gives the ff example: dying in childhood, a victim of paralysis, and empirical contingency/weakness of an organism. It can also be that it is an incomplete one in the course of the unfolding of one's core. Stein $(1989,111)$ likens it to a "fragmentary work of art of which a part is finished, and only the raw material for the rest is preserved...A defective unfolding is also possible in a sound organism. He who never meets a person worthy of love or hate can never experience the depths in which love and hate are rooted... Such an 'incomplete person' is similar to an unfinished sketch." She $(1989,111)$ adds: "Finally, it is also conceivable for the personality not to unfold at all. He who does not feel values himself but acquires all feelings only through contagion from others cannot experience "himself." He can become, not a personality, but at most a phantom of one." 8 The spiritual person exists though it is not unfolded. But the important thing is that this personality core is mine alone and cannot be had by anybody else.

After finishing her doctorate in philosophy in 1916, Stein published phenomenological treatises in Husserl's Jahrbuch, among which is "Philosophy of Psychology and Humanities." In the second part of the work, she deepened her notion of core-personality, which she began to explore in her dissertation. She (2000, 238) writes: "The human personality considered as a whole, shows itself to us as a unity of qualitative distinctiveness that is fashioned out of a core, a formative root. It takes shape in soul, body, and mind, but only in your soul does individuality achieve clear and unambiguous expression." 9 From a core-personality that cannot deteriorate but can unfold, Stein develops it to be the root of human qualities and distinctiveness. 
The core-personality is a formative root that develops in the unity of the human person's soul, mind, and body and somehow "colors" the human person's perception of the world without reducing the meaningfulness of the world according to each human person's perception. Because of this core, for Stein $(2000,230)$, "the world strikes a chord within your soul, and in a special way in each individual soul." 10 The world is presented to us in a way that is different to each person because of this core that is ours alone. Each is susceptible to the many types of values, and the way we take these values vary because of our core. We can identify who this person is because of the values he takes. Stein $(2000,227)$ avers:

Now with a person, 'to take a stance' is the 'natural orientation.' A person does not confront us as a value-free being, but rather as a valuetropic being (i.e., to exist in a value attached manner). The value response is the 'most natural' behavior for a person, and accordingly, for the properties in which value is predominantly evident to her as well...We see what the person is when we see which world of value she lives in, which value she is responsive to, and what achievements she may be creating, prompted by values.

Furthermore, Stein (2000, 92-93) sees this core as describing us substantially that we do not have the power to change its structure ${ }^{11}$ and is so hidden that only someone other-worldly can change it. For Stein (2000, 233), only an "other-worldly" power can. ${ }^{12}$ This other-worldly power is outside all our natural processes and entanglements. She $(2000,233)$ declares:

As withdrawn from all influences, this inner sphere is inaccessible not only for all extrinsic effects but also for self-education. Any work on yourself, any effects toward a cleansing of your soul can consist only in this: to suppress negatively valued deeds and stirrings of your soul and to combat the disposition to them, or even not to let them arise, and conversely to hold yourself open for positive values. But you can neither instill the qualities of your soul into yourself nor break yourself of them. If a change enters into this sphere, then it is not an occurrence of a 'development' but rather is to be regarded as a transformation through an 'other-worldly' power, that is, a power situated outside of a person and outside of all natural connections in which she is entangled.

Stein's core-personality is the root principle why the human individual in a community cannot possibly be absorbed by all-encompassing communal experiences. It is also what preserves the uniqueness of the human individual within the context of the community. In short, in Stein's thought, the individual human person is ontologically prior to the community but without denying that he can stand apart from the community. The human individual depends, so to speak, on his community. On the other hand, the community can be traced back to its members but without denying that it has a reality of its own. The human person's core-personality, i.e., man's irreducibility, is never removed even within the context of the community, no matter 
how intense that communal experience is. Stein $(2000,263)$ asserts: "But even where the person is the very image of the communal type, her being is not exhausted in that. Analysis of the individual personality shows that it belongs directly to the essence of the person not to be a mere instantiation of a typical property, but rather to possess an individual core which also lends to every typical character trait an individual stamp."

To summarize, although subjectivity for Wojtyla and core-personality for Stein are different, we can conclude the following: 1. Both spell out the uniqueness of human beings; 2. Both are hidden and not public; 3. Both are not reducible to any created reality; 4. Both are essential constituents of the proper understanding of the human person; 5. And in terms of method, both philosophers use the phenomenological method but avoided what can be termed as Husserl's transcendental turn.

\section{WHY AND NOT WHAT}

What and what are not mere questions posed but refer primarily to a kind of human disposition and actuations. What refers to a kind of disposition which sees and understands man just like any other in the created world. However, subjectivity and core-personality are not something discovered like an object out there, nor can these concepts be likened to any object in the world, public and manifested to the physical eyes. It lies within and is hidden most of the time. Subjectivity and core-personality are often missed for the reason that it is so easy for us to see the human being just like any other physical object in the world. With this attitude, it is easy to exploit the other, like crushing a piece of paper or putting a candy wrapper in the trash can. Some people find it easy to harm or even kill those they regard "non-persons" and mutilate without a moment of remorse the other's body after raping her in a dark alley. The "what-disposition" sees no distinction between the money on the table and the woman in front of me. It can even give much emphasis on the value of the former in exchange for the pleasure to be derived from the latter.

On the other hand, asking the why refers to a disposition that seeks what is hidden and yet to be revealed as if shedding light on what is already there but most of the time not thematized and understood. It is a kind of mentality that does not equate human beings to any other kind of physical object in the world. There is a certain strength in human subjectivity and core-personality that cannot possibly be reduced to anything material. Its value goes beyond space and time. It has a structure that lies hidden and that only a person himself in this second kind of disposition can see and actualize. We can say that this value cannot be effaced and can only be responded to properly: respect, compassion, justice, truth, and love.

One thread that runs throughout Wojtyla's pontificate is his defense of the rights and dignity of the human person from the womb to the tomb. In particular, he devoted his whole life, his priestly ministry, to deepening our understanding and safeguarding human subjectivity. He has rendered a great service to the whole world in this respect. On the other hand, Stein's life, ceaseless search for the truth, and martyrdom are symbols, especially towards the end of her life when she was murdered in Auschwitz, of vicarious offering, respect, compassion, and empathy, especially to those Jews who were considered and treated as society's refuse and on 
the level of animals. Hers is a life and a witness that no amount of totalitarian power and tyranny can intimidate, crush, and pulverized the human person's corepersonality. She is a victim of injustice herself, but there is always a limit to evil! Wojtyla's sanctity and Stein's martyrdom are different instances in human history wherein pausing at the irreducible brings about an impact that resonates until now and at this very moment. Though different in context and background, but not denying their similarities, theirs asked why that led to service and supreme sacrifice of giving oneself to the other. They refused to go with the flow of the majority, which most of the time have not understood the worth of each human being.

We are now aware that subjectivity and core-personality are not just mere concepts and excogitations of the mind of these two saints, but more strongly, are challenges that painfully clamor and constantly sting us like a gadfly. Honestly, we still have a long way to go to fully realize it. And perhaps the reason why we still have a long way to go is that we really need to "pause before the irreducible."

\section{SOME QUESTIONS AND POSSIBLE REPLIES}

Can we speak of various kinds of subjectivities and core-personalities? I humbly propose that subjectivity can be weak or strong. As Crosby (1996, 82ff) states: one form of weak subjectivity is what we call scattered subjectivity. It is a kind of subjectivity in which a person is drawn to so many things and thus lives a life of dissipation. This kind of subjectivity lets itself be absorbed by so many things that make him fragmented, the result of which is one becomes vulnerable to others' impulses. He does not have a strong sense of self to face the world. On the contrary, the world acts on him, and he receives it passively.

How do we cure a scattered subjectivity? How can we re-invigorate a dissipated subjectivity? The answer is through recollection. To recollect one's self is to recover a fragmented self. As von Hildebrand claims $(1990,105)$, it is to go back to one's center. It produces a strong self-presence that gives space and distance to things that threaten to swallow you. It is not so much an enlarged self-presence as a strengthened and revived self-presence. It does not mean escaping the vicissitudes of life. On the contrary, recollection makes one's subjectivity return to the world with renewed vigor, ready to face it without letting itself be eaten up by so much preoccupation. By this, one has more freedom and power.

Hence, only the act of recollection can make me say "I" in the full force of the word. Thus, I am not swallowed up by so many things that lead me to a life of dissipation, for I am gathered to myself as a person. In this sense, only "I" can make the act of recollection, and no one else can do it for me.

Can we speak likewise of core-personality, according to St. Edith Stein? My suggested answer is affirmative, which can run parallel to the above, but the direction is along with Stein's understanding of the relation between core-personality, soul, and Lifepower. ${ }^{13}$

Let us take the point made by Stein in her work Philosophy of Psychology and Humanities. In Stein's second treatise entitled Individual and Community and in the context of her discussions of soul and core of the person, we can infer and distinguish 
between two types of human behaviors. Following the thoughts of her godmother and another phenomenologist Hedwig-Conrad Martius, Stein speaks about a soulless behavior, which means a kind of human behavior and action that left the center of one's soul and core untouched. She $(2000,229)$ writes:

There is a kind of on-going experiencing in which, according to a depiction by Hedwig -Conrad Martius, your soul isn't 'stimulated' too and which has not gone through your 'central self.' It pertains to the unity of your psyche but doesn't issue from your core, and your soul is not implicated in [this experiencing]... The sphere of emotion....appears to me like the 'body' of the soul, as it were, or like its special peripheral self. Just as every external impression is detected directly on the physical body, so also on this 'body' of the soul, every 'inner' impression [is detected]. But as long as the soul is not involved with it centrally, there is only a superficial sensation - a mere 'stimulation' and a reaction to the stimulus. In no way at all does the entirety of the soul invest itself in this region of specific, sensory experiencing and reacting. [In this region], we are getting only the 'sheath' of the soul.

This soul-less behavior can be seen in the following effects. We can already discern its parallelism with a scattered subjectivity mentioned above. Stein (2000, 234) claims:

There is an absorption into peripheral experiences if the depth of your soul hasn't been awakened. Emotional disturbances as well, which 'properly' lay claim to being experienced in the depths, then play themselves out on the periphery, and that does not noticeable to the individual as a deficiency as long as the individual knows nothing at all of his own depth. There is an escaping from the depths to the periphery to the point when a person's soul life turns into torment for her when the soul is filled with distress.

She $(2000,234)$ continues: "[There] is a pervasive rigidity of your soul against all endeavors, running dry of its life. The ego descends into its depths; it holes up there. Yet, the ego meets a gaping void in there. The ego gets the feeling that it is missing its soul, that it is only a shadow of itself detached from its own most being."

On the other hand, Stein claims there is another kind of human action that we can call an awakened soul. She (2000, 233) writes: "And if the world 'crashes in anew, and always new, in each single human being', then what is coming to expression there is that the soul is becoming itself anew and always new... Your soul is ripening and imprinting that development with its trademark... What can help your soul to an awakening?... Anything and everything can suddenly strike in the depths, to where nothing was able to make headway before... Rather, the whole abundance of your soul bursts forth in the actuality of living, an actuality which discloses that that living is just now becoming 'soul-filled."' 
Stein (2000, 234-235) continues to make it more precise: "In order to illuminate this matter, we've got to make clear for ourselves what is meant by this: to live from out of your soul. It means that life in action not only reflects the qualities of your soul but also pours out your soul and is its life... Your soul itself is a source of life. If your soul is awake, then these new powers are flowing to the mental life, and it is as if the world rises up brand new in front of the individual experiencing [this]." Then she (Stein 2000, 235) added: "It can also happen that your soul, without getting switch off, stops generating life. The source hidden in your soul can sputter out... and the interior seems emptied of everything that used to fill it, everything in which the individuality, itself ineffable, used to articulate itself...A person can also gradually shrivel up through constant excessive expenditure of power, and she's got to have new powers supplied to her from an extraneous source so that she rouses again to new life."

What can awaken a soul and the development of the core-personality? Stein $(2000,232)$ insists that the community has a major role to play in the formation of the individual. "The external circumstances play a double role: they determine the waxing and waning of life power, and they also determine the direction of development, but to be sure, only within the latitude that the original predisposition plainly allows." She $(2000,200)$ concludes: "So the formation of the psyche of any individual is also owing to 'external circumstances' - apart from his or her original predispositions, life power and will. The circumstances under which the individual's life proceeds are also responsible for the formation of his or her psyche."

That is why we can see that inside the community, various components of members are to be found that influence the community and its members. Stein (2000, 204) enumerates those that "give mighty impulses," those that "enrich it only a little," and "those who draw off more than they contribute." One has the power to propel others to develop. So each member of the community must be co-responsible in the development of each. She $(2000,205)$ proceeds further:

It seems that these overlapping causal relationships can help the individual along not only during a temporary failure of her power but may even make her capable of achievements that she would not be able to pull off on her own even with her life power at optimal status.

Aside from the power of individuals, Stein underlines the significance of social attitudes. There are attitudes that affect an individual's core: 1) positive (love, trust, gratitude, faith in a human being), 2) negative (distrust, aversion, hatred), and 3) indifference (neither love nor hatred). She (2000, 211-212) explains: "The contents as such - the love, the hatred, the trust, and so forth - deploy a specific efficacy within the human beings whom they befall. The love which I meet with strengthens and invigorates me and grants me the power for unexpected achievements. The distrust that I run into disables my creative power. Other people's attitudes encroach directly upon my inner life and control its course." She $(2000,212)$ further claims:

Love and the positive attitudes, in general, do not feed upon themselves; instead, they are a font from which I can nourish others without impoverishing myself. This font is inexhaustible in 
itself...Thus, in subjectivity, we already have sources of life that elude all measure and all calculation, which benefit the causal mechanism as propellant powers but are not subject to any control themselves.

\section{CONCLUSION}

In this paper, we have attempted to present the many convergences and differences of these two saints, in particular, some introductory and suggestive themes in Wojtyla's and Stein's notion of human individuality. We have also seen the paramount importance of pausing at the irreducible and not approach it from the vantage point of the what. Finally, we tried to answer whether we can speak of various kinds of subjectivities and personality cores. It is evident towards the end that though the two approached it from different angles, we can still conclude that they illumine each other, for saints are kindred in spirit.

Many themes were left out for future investigations, i.e., community, values, participation, and how their understanding of human individuality developed when in dialogue with Scholasticism, in particular, Thomas Aquinas. These topics will be of interest as we continue to delve more deeply into their writings.

As of the moment, both were being considered as doctors of the church, as we said above. We pray that with the depth and impact of their thoughts, the title may be bestowed to them by the church for the glory of God and the sanctification of men/women.

Laus Deo!

\section{NOTES}

1. This author suggests that the Wojtylan subjectivity is, in a sense, akin to the Schelerian notion of the individual person. Further studies comparing the two are worthwhile.

2. We find strong echoes here of Scheler's notion of the individual person. Also, the above assertion does not imply that I have knowledge of myself that God does not have. It only means that I have "something irreducible" in me that no human being can replicate.

3. This is one of the key reasons why seeing the person as self-presence excludes the doubt of solipsism and extreme individualism.

4. One should note that Edith Stein uses the term "soul" in various ways. Pls see (Stein, 1989, 40; 2002, 427 ff; 2006, 114-115; 2009, 230 ff).

5. Stein (2000, 228-229) also said: "There are sentient and physical processes that are indifferent with regard to the unified pattern, the 'personality,' and do not bear its trademark. They do not matter for your soul. What is of the soul is rooted in the core."

6. The sense of "development" must be clarified. Development is not understood as the movement from potency to act. Development in this context is, as Borden Sharkey $(2010,12)$ writes: "the unfolding of essential possibilities, that is, possibilities of some essential structures." 
7. Also, Stein (2000, 231-232) claims in another of her works: "No development is exhibited by the core of the person or by the being of the soul that is determined by it. The living of the psyche is a developmental path in which (sentient) abilities get training. Prerequisites of this training are the powers that the person is equipped with, the external circumstances under which the living proceeds, and finally, the 'original predisposition' that more or less attains deployment within the process of development. The external circumstances play a double role: they determine the waxing and waning of life power, and they also determine the direction of development, but to be sure, only within the latitude that the original predisposition plainly allows. If you possess no mathematical aptitude, even the most exquisite instruction will not make the mathematician out of you. But if you are gifted, the specialty to which you apply yourself can depend on the direction in which your gaze is turned through outside influences. The original predisposition undergirds the development yet does not itself develop. Under favorable circumstances, more of it comes to light than under unfavorable ones. But the predisposition itself does not take up anything new into itself, nor does it lose anything of its substance."

Following Scheler's lead in his tripartite anthropology, Stein made distinctive contributions of her own. She sees the human being as porous and stratified, composed of four divisions, each has its own activity but in no way isolated from each other. Influences travel from one to the other. The four divisions are physical (matter, the physical component of the body), sensate (sentience, the living responsive body), mental (intelligence, mind), personal (individual person, unique personality). Pls. see (Stein 2000, xvi-xvii).

8. It brings to mind one of Scheler's notions that runs parallel to what Stein says: heteropathic identification. Scheler $(2008,18)$ explains it as: "where 'I' (the formal subject) am so overwhelmed and hypnotically bound and fettered by the other 'I' (the concrete individual), that my formal status as a subject is usurped by the other's personality, with all its characteristic aspects; in such a case, I live, not in 'myself,' but entirely in 'him,' the other person."

9. Stein $(2000,92-93)$ also said: "We know that the sentient state of the person at any given time does not depend only upon the 'history' of her life and the present 'circumstances.' Rather, her entire life is decided by the 'core personality,' by that invariable repertoire of being that is not a result of development but, on the contrary, prescribes how the development proceeds."

10. Stein $(2000,228)$ further writes: "The human being lives out of his soul, which is the center of his being. But this centered orientation does not imply that the total ego, which deploys itself in soul, body, and mind, is fashioned and pervasively determined by the soul. It's more like the soul grows out of a root that determines the being of the individual soul-essence as a whole, in all its dimensions. If we regard this root or this 'core' as the template out of which the being of the individual fashions itself, then...there are sentient and physical processes that are indifferent with regard to the unified pattern, the 'personality,' and do not bear its trademark. They do not matter for your soul. What's of the soul is rooted in the core." In Stein (2000, 237 footnote no. 157), the editor and translator comments: "Stein insists that the personal core has priority over the soul and determines it. This is in keeping with her conception of four phenomenal regions of the human being: the physical, the 
sentient, the mental, the personal. The soul is not a simple derivative to any of these but is derivative of them."

11. She (2000, 92-93) writes: "Her entire life is decided by the "corepersonality,' by that invariable repertoire of being that is not a result of development but, on the contrary, prescribes how the development proceeds."

12. This author suggests that this hiddenness echoes Wojtyla's understanding of subjectivity.

13. Christof Betschart, O.C.D. $(2016,82)$ writes: "According to Stein, the soul and the core are absolutely individual. She maintains that the two do not change as the person grows and develops, though the core and the soul remain distinct. So, why does Stein make this distinction? In her Munster anthropology, she affirms that soul and core are synonymous terms. In my view, the distinction is only present in Stein's earlier work because she had not yet read the metaphysics of Hedwig-Conrad Martius and developed her own phenomenological work."

\section{REFERENCES}

Betschart, Christof. 2016. The individuality of the human person in the phenomenological works of Edith Stein. In Edith Stein: women, social-political philosophy, theology, metaphysics and public history. Switzerland: Springer International Publishing.

Borden Sharkey, Sarah. 2006. What makes you you? Individuality in Edith Stein. In Contemplating Edith Stein. Edited by Joyce Avrech Berkman. Indiana: University of Notre Dame Press.

Borden Sharkey, Sarah. 2010. Thine own self: individuality in Edith Stein's later writings. Washington, DC: CUA, Press.

Crosby, John. 1996. The selfhood of the human person. Washington, DC: CUA Press.

Lebech, Mette. 2002. Why does John Paul II refer to Edith Stein. In Fides et Ratio: The Challenge of Truth Reflections on Fides et Ratio. Edited by James McEvoy. Dublin: Veritas Publications.

Pieper, Josef. 1998. Leisure, the basis of culture. Translated by Gerald Malsbary. Indiana: St. Augustine Press.

Scheler, Max. 2008. The nature of sympathy. Translated by Peter Heath with an Introduction by Werner Stark and a new introduction by Graham McAleer. New Brunswick: Transaction Publishers.

Stein, Edith. 1986. Life in a Jewish family. Translated by Josephine Koeppel, Ph.D. Washington, DC: ICS Publications.

Stein, Edith. 1989. On the problem of empathy. Translated by Waltraud Stein, Ph.D. Washington, DC: ICS Publications.

Stein, Edith. 2000. Philosophy of psychology and humanities. Translated by Mary Catharine Baseheart and Marianne Sawicki. Washington, DC: ICS Publications.

Stein, Edith. 2002. Finite and eternal being an attempt at an ascent to the meaning of being. Translated by Kurt Reinhardt. Washington, DC: ICS Publications.

Stein, Edith. 2006. An investigation concerning the state. Translated by Marianne Sawicki. Washington, DC: ICS Publications. 
Stein, Edith. 2009. Potency and act studies toward a philosophy of being. Translated by Walter Redmond. Washington, DC: ICS Publications.

Wojtyla, Karol. 1993. Person and community selected essays. Translated by Theresa Sandok. New York: Peter Lang.

Wojtyla, Karol. 1979. The acting person. Translated by Andrzej Potocki in collaboration with Cardinal Karol Wojtyla by Anna-Teresa Tymieniecka. Dordrecht, Holland; Boston, USA: D. Reidel Publishing Company.

Von Hildebrand, Dietrich. 1990. Transformation in Christ. New Hampshire: Sophia Institute Press. 